\title{
EFIKASI INSEKTISIDA NABATI EKSTRAK DAUN Tephrosia vogelii Hook. TERHADAP Crocidolomia pavonana (F.) dan Plutella xylostella (L.) SERTA PENGARUHNYA PADA Diadegma semiclausum (Hellen)
}

\author{
Agustin Zarkani $^{1}$, Djoko Prijono ${ }^{2}$, Pudjianto ${ }^{2}$ \\ ${ }^{1)}$ Departemen Proteksi Tanaman, Fakultas Pertanian UNIB \\ ${ }^{2)}$ Departemen Proteksi Tanaman, Fakultas Pertanian IPB \\ Jln. Raya Kandang Limun Bengkulu 38371A \\ abuiffah@yahoo.co.id
}

\begin{abstract}
[EFICATION OF BOTANICAL INSECTICIDE OF Tephrosia vogelii Hook. f. LEAF EXTRACT AGAINTS Crocidolomia pavonana (F.) AND Plutella xylostella (L.) AND ITS EFFECT TO Diadegma semiclausum (Hellen)]. The active fraction of hexane extract of Tephrosia vogelii (Tv) leaves was evaluated for this insecticidal activity on second-instar larvae of Crocidolomia pavonana and Plutella xylostella as well as for the safety to the adults of Diadegma semiclausum parasitoid. Fraction (fr) 2-4 of $T v$ from column chromatography (CC) had strong insecticidal activity on C. pavonana and P. xylostella. In the test with C. pavonana, the fraction was more active by feeding than by contact. Based on $\mathrm{LC}_{50}$ at 72 hours since treatment (HST), fr 2-4 CC Tv was 1.8 times more toxic to P. xylostella than to $C$. pavonana. The fr 2-4 CC Tv showed strong antifeedant effect against $C$. pavonana larvae. At equal test concentrations, the treatment with fr 2-4 CC Tv caused much lower mortality in D. semiclausum parasitoid adults than in its host larvae, P. xylostella. In contrast, an organophosphate profenofos, included in this study as a positive control, was much more detrimental to D. semiclausum than to $P$. xylostella. In the semifield experiment, fr 2-4 CC $T v$ had comparable effect with profenofos and bioinsecticide Bacillus thuringiensis in reducing the population of $C$. pavonana larvae on broccoli plants.
\end{abstract}

Keyword: lethal effect, antifeedant effect, brassica pests, parasitoid.

\begin{abstract}
ABSTRAK
Fraksi aktif dari ekstrak heksana daun Tephrosia vogelii $(T v)$ telah dievaluasi aktivitas insektisidanya terhadap larva instar ke-2 Crocidolomia pavonana dan Plutella xylostella serta keamannya terhadap serangga dewasa parasitoid Diadegma semiclausum. Fraksi (fr) 2-4 Tv dari kromatografi kolom (KK) memiliki aktivitas insektisida yang kuat terhadap C. pavonana dan P. xylostella. Pengujian terhadap C. pavonana, fr 2-4 Tv lebih aktif melalui makan dibandingkan dengan melalui kontak. Berdasarkan $\mathrm{LC}_{50}$ pada 72 jam setelah perlakuan (JSP), fr 2-4 KK Tv 1,8 kali lebih beracun terhadap $P$. xylostella dibandingkan dengan $C$. pavonana. Fr 2-4 KK Tv menunjukan efek antifeedant kuat terhadap larva $C$. pavonana. Melalui uji konsentrasi yang setara, perlakuan dengan fr 2-4 KK $T v$ menyebabkan kematian lebih rendah terhadap parasitoid dewasa $D$. semiclausum dibandingkan dengan larva inangnya, $P$. xylostella. Berbeda dengan organophosphate profenofos, sebagai kontrol positif, bersifat lebih detrimental terhadap D. semiclausum dibandingkan dengan P. xylostella. Melalui uji semilapangan, fr 2-4 KK Tv memiliki efek yang berbeda dengan profenofos dan bioinsektisida Bacillus thuringiensis dalam mengurangi populasi larva C. pavonana pada tanaman brokoli.
\end{abstract}

Kata kunci: efek letal, efek antifeedant, hama brassica, parasitoid 


\section{PENDAHULUAN}

Kendala utama dalam budidaya tanaman kubis adalah serangan ulat Crocidolomia pavonana (F.) (Lepidoptera: Crambidae) dan Plutella xylostella (L.) (Lepidoptera: Yponomeutidae) (Sastrosiswojo dan Setiawati, 1992; Talekar and Shelton, 1993). Serangan kedua jenis hama tersebut secara bersamasama dapat menyebabkan gagal panen jika pengendalian tidak dilakukan, khususnya pada musim kemarau (Kalshoven, 1981; Sastrosiswojo dan Setiawati, 1993).

Saat ini, pengendalian larva $C$. pavonana dan $P$. xylostella umumnya masih menggunakan insektisida sintetik. Cepatnya pertumbuhan dan perkembangan $C$. pavonana dan $P$. xylostella dengan daya makan yang tinggi serta keterbatasan keefektifan pengendalian nonkimia di tingkat petani menjadi alasan petani menggunakan insektisida sintetik dalam mengendalikannya (Smith, 1975; Setiawati dan Sastrosiswojo, 1995). Namun demikian, penggunaan insektisida sintetik secara terus-menerus dan berlebihan dapat mengakibatkan berbagai dampak negatif seperti resistensi dan resurjensi hama, ledakan populasi hama sekunder, serta keracunan pada hewan ternak dan manusia (Metcalf, 1982; Matsumura, 1985; Rush et al., 1997) sehingga perlu dicarikan alternatif pengendalian lain yang lebih aman dan ramah lingkungan.

Salah satu sarana pengendalian hama alternatif yang layak dikembangkan ialah insektisida nabati karena senyawa insektisida dari tumbuhan mudah terurai di lingkungan (Coats, 1994; Isman, 1995; Kaufman et al., 2006) dan relatif aman terhadap organisme bukan sasaran (Bentz and Neal, 1995; Schmutterer, 1997; Dono et al., 1998). Selain itu, insektisida nabati tertentu juga relatif lebih murah dan mudah diperoleh dibandingkan dengan insektisida sintetik, tidak cepat menimbulkan resistensi hama bila digunakan dalam bentuk ekstrak kasar, komponen ekstrak dapat bersifat sinergis, dan penggunaannya dapat dipadukan dengan teknik pengendalian hama lainnya (Prijono, 1999).

Di antara tumbuh-tumbuhan yang memiliki potensi sebagai sumber insektisida nabati ialah Tephrosia vogelii Hook. f. (Fabaceae). Daun T. vogelii mengandung senyawa rotenoid yang bersifat insektisida termasuk rotenon, deguelin, dan tefrosin (Delfel et al., 1970; Hagemann et al., 1972; Marston et al., 1984; Lambert et al., 1993). Rotenon bekerja sebagai racun respirasi sel dengan menghambat transfer elektron dalam NADH-koenzim ubikuinon reduktase (kompleks I) dari sistem transpor elektron di dalam mitokondria (Hollingworth, 2001).
Untuk itu, evaluasi potensi $T$. vogelii sebagai insektisida nabati perlu dilakukan sebagai pertimbangan dalam pengendalian hama $C$. pavonana dan P. xylostella. Aspek keamanan insektisida nabati tersebut terhadap musuh alami Diadegma semiclausum juga perlu dievaluasi sebagai salah satu landasan penerapannya dalam pengendalian hama terpadu.

Penelitian ini bertujuan menguji (1) efek racun perut dan kontak komponen ekstrak daun $T$. vogelii $(T v)$ terhadap larva $C$. pavonana; (2) efek racun perut fraksi aktif $T v$ terhadap larva $P$. xylostella; (3) keamanan fraksi aktif $T v$ terhadap imago parasitoid D. semiclausum; dan (4) keefektifan fraksi aktif $T v$ terhadap larva $C$. pavonana pada tanaman brokoli dalam polybag di lapangan.

\section{METODE PENELITIAN}

Penelitian dilaksanakan di Laboratorium Fisiologi dan Toksikologi Serangga, Departemen Proteksi Tanaman, Fakultas Pertanian IPB dan Kebun Percobaan Cikabayan IPB. Bahan tumbuhan yang digunakan sebagai sumber ekstrak ialah daun $T$. vogelii, yang diperoleh dari Lembaga Pertanian Sehat, Dompet Dhuafa Republika di Kecamatan Caringin, Kabupaten Bogor (636 m dpl, 60 44' 44.7"' LS dan $106^{0} 49^{\prime} 57.5^{\prime \prime}$ BT). Sebagai insektisida pembanding digunakan formulasi yang mengandung bahan aktif Bacillus thuringiensis (Turex WP, deltaendotoksin B. thuringiensis var. aizawai strain GC$913.8 \%, 25,000 \mathrm{IU} \mathrm{mg}^{-1}$ ) dan profenofos (Curacron $500 \mathrm{EC}$, kadar bahan aktif $499.53 \mathrm{~g} \mathrm{~L}^{-1}$ ), yang masing-masing diperoleh dari PT. Tanindo Subur Prima dan PT. Syngenta Indonesia, Jakarta.

\section{Ekstraksi dan Fraksinasi T. vogelii}

Simplisia bahan uji dihaluskan dengan blender dan diayak dengan pengayak bermata $0.5 \mathrm{~mm}$. Ekstrak T. vogelii diperoleh dengan maserasi $300 \mathrm{~g}$ serbuk daun dengan heksana. Ekstrak $T$. vogelii (Tv) difraksinasi dengan kromatografi vakum cair (KVC) dengan penjerap Silica Gel $60 \mathrm{~F}_{254}(40-63 \mu \mathrm{m})$ seperti yang dikemukakan oleh Coll and Bowden (1986). Pelarut yang digunakan adalah diklorometan dan etil asetat dengan perbandingan berturut-turut 1:0, 9:1, dan 0:1. Fraksi yang diperoleh diperiksa kehomogenannya dengan kromatografi lapisan tipis (KLT) menggunakan pelat aluminium berpenjerap Silica Gel $60 \mathrm{~F}_{254}$, pelarut pengembang kloroformdietil eter (19:1), dan bercak komponen dideteksi dengan penyinaran ultraviolet $\lambda 254 \mathrm{~nm}$. Fraksi 
dengan retention factor ( $\mathrm{Rf}$ ) sama disatukan kemudian diuji terhadap larva $C$. pavonana. Kromatogram fraksi aktif $T v$ pada pelat KLT dibandingkan dengan standar rotenon.

\section{Uji Toksisitas terhadap Larva C. pavonana dan P.} Xylostella

Metode residu pada daun. Ekstrak $T v$, fraksi aktif $T v$, dan campurannya diuji terhadap larva $C$. pavonana pada lima taraf konsentrasi yang diharapkan dapat menyebabkan kematian serangga uji antara $>0 \%$ dan $<100 \%$ (berdasarkan uji pendahuluan). Ekstrak atau fraksi dilarutkan dalam campuran metanol, aseton, dan Tween 80 (5:5:2) kemudian diencerkan dengan akuades hingga volume yang diinginkan (konsentrasi akhir metanol + aseton + Tween $801.2 \%$ ) [larutan kontrol: air yang mengandung pelarut dan pengemulsi tersebut]. Larva instar II $C$. pavonana diberi makan daun brokoli perlakuan atau kontrol selama 48 jam, kemudian diberi makan daun tanpa perlakuan selama 24 jam berikutnya. Fraksi aktif $T v$ serta campurannya juga diuji terhadap larva $P$. xylostella dengan metode yang sama. Untuk setiap perlakuan dan kontrol digunakan 75 larva $C$. pavonana atau 40 larva $P$. xylostella. Jumlah larva yang mati dicatat setiap hari hingga hari ke-3. Data kematian serangga uji diolah dengan analisis probit (Finney, 1971) menggunakan program POLO-PC (LeOra Software, 1987).

Untuk campuran ekstrak yang berasal dari jenis tumbuhan yang sama, sifat aktivitas campuran dianalisis berdasarkan model kerja bersama serupa dengan menghitung nisbah ko-toksisitas (NK) pada taraf $\mathrm{LC}_{50}$ dan $\mathrm{LC}_{95}$ seperti yang dikemukakan oleh Wadley (1945 dalam Kosman and Cohen, 1996).

Metode kontak. Ekstrak kasar $T v$ dan fraksi aktif $T v$ diuji toksisitas kontaknya terhadap larva $C$. pavonana dengan metode residu pada permukaan gelas pada konsentrasi 1-4 kali $\mathrm{LC}_{95}$ berdasarkan hasil pengujian dengan metode residu pada daun. Insektisida sintetik profenofos digunakan sebagai pembanding positif.

Setiap bahan uji dilarutkan dalam aseton sedangkan kontrol hanya mengandung aseton. Setiap larutan uji dipipet sebanyak $0.5 \mathrm{~mL}$ ke dalam tabung gelas berdiameter $2.2 \mathrm{~cm}$ dan tinggi $5.8 \mathrm{~cm}$. Setelah kering, ke dalam setiap tabung dimasukkan 15 larva instar II C. pavonana yang berumur sekitar 3-4 jam setelah ganti kulit. Setelah 2 jam kontak, larva uji dipindahkan ke dalam cawan petri yang dialasi tisu dan berisi potongan daun brokoli $4 \mathrm{~cm} \mathrm{x} 4 \mathrm{~cm}$ tanpa perlakuan. Setiap perlakuan diulang lima kali.
Jumlah larva yang mati dihitung pada 24 jam setelah pemindahan ke cawan petri.

\section{Uji Toksisitas Fraksi Aktif T. vogelii terhadap Imago Parasitoid D. Semiclausum}

Fraksi aktif $T v$ diuji terhadap imago parasitoid D. semiclausum dengan metode kontak pada permukaan daun. Konsentrasi yang diuji ialah ialah $1 \times \mathrm{LC}_{95}$ dan $2 \mathrm{x} \mathrm{LC}_{95}$ tertinggi berdasarkan hasil pengujian terhadap larva $C$. pavonana dan $P$. xylostella. Penyiapan bahan uji dilakukan seperti pada pengujian toksisitas dengan metode residu pada daun dan sebagai pembanding digunakan insektisida sintetik profenofos (Curacron 500 EC).

Satu lembar daun brokoli bertangkai dipotong helaian daunnya sehingga menyisakan helaian daun berukuran $5 \mathrm{~cm} \times 5 \mathrm{~cm}$. Daun selanjutnya dicelupkan dalam suspensi bahan uji hingga membasahi permukaan secara merata, kemudian tangkai setiap helaian daun uji dimasukkan dalam botol film berisi air dan diletakkan di dalam kurungan plastik (tinggi $4.5 \mathrm{~cm}$ dan diameter $3.5 \mathrm{~cm}$ ). Sebanyak 10 ekor imago betina dan jantan parasitoid $D$. semiclausum yang berumur 3-4 hari dimasukkan ke dalam setiap kurungan plastik pengujian dan diberi pakan madu $10 \%$ yang diserapkan pada kapas. Imago parasitoid dibiarkan kontak dengan residu bahan uji pada daun brokoli selama 72 jam. Jumlah serangga uji yang mati dicatat setiap hari sampai hari ke-3.

\section{Uji Semilapangan Fraksi Aktif T. vogelii terhadap Larva C. Pavonana}

Tanaman brokoli (Brassica oleracea L. var. italica Plenck) cv. Winter Harvest -yang diperoleh dari petani organik Desa Babakan, Kecamatan Darmaga, Kabupaten Bogor dan berumur 1 bulan dipindahkan ke dalam polybag $5 \mathrm{~L}$ dan dipelihara hingga memiliki 5-6 helai daun. Selanjutnya tanaman brokoli tersebut diletakkan di lahan percobaan Cikabayan, IPB.

Percobaan disusun dalam rancangan acak kelompok dengan perlakuan (1) fraksi 2-4 KK $T$. vogelii $0.135 \%$, (2) formulasi Bacillus thuringiensis (TurexWP) $0.0552 \%$, (3) formulasi profenofos (Curacron 500 EC) $0.0900 \%$, dan (4) kontrol. Konsentrasi yang diuji setara dengan $3 \times \mathrm{LC}_{95}$ terhadap larva instar II $C$. pavonana pada pengujian dengan metode residu pada daun di laboratorium. Tiap unit perlakuan terdiri atas dua tanaman brokoli dengan empat ulangan.

Sediaan bahan uji disemprotkan pada tanaman 
brokoli dengan menggunakan hand sprayer pada permukaan atas dan bawah daun hingga merata. Pada salah satu tanaman brokoli diinfestasikan 15 larva instar II $C$. pavonana segera setelah cairan semprot mengering dan 7 hari kemudian dilakukan infestasi ulang dengan jumlah larva uji yang sama pada tanaman brokoli kedua. Jumlah larva yang masih hidup dicatat pada 3, 4, dan 7 hari setelah infestasi pertama dan kedua. Data diolah dengan sidik ragam yang dilanjutkan dengan uji selang berganda Duncan $(\alpha=5 \%)$.

\section{HASIL DAN PEMBAHASAN}

\section{Ekstraksi dan Fraksinasi T. Vogelii}

Pemisahan $9 \mathrm{~g}$ ekstrak heksana daun $T$. vogelii (Tv) dengan KVC menghasilkan fraksi $\mathrm{CH}_{2} \mathrm{Cl}_{2}$ $6.79 \mathrm{~g}\left(75.44 \%\right.$ ), fraksi $\mathrm{CH}_{2} \mathrm{Cl}_{2}-\mathrm{EtOAc}$ (9:1) $0.40 \mathrm{~g}$ (4.44 \%), fraksi EtOAc $0.41 \mathrm{~g}(4.56 \%)$, dan fraksi
$\mathrm{MeOH} 1.29 \mathrm{~g}(14.33 \%)$. Pemeriksaan fraksi-fraksi tersebut dengan KLT menghasilkan lima fraksi (Tabel 1). Pemurnian fraksi yang aktif (fraksi 2 dan 3) dengan kromatografi kolom (KK, eluen $\mathrm{CH}_{2} \mathrm{Cl}_{2}$-EtOAc 9:1, EtOAc, dan $\mathrm{MeOH}$ ) masingmasing menghasilkan lima subfraksi dengan aktivitas tertinggi terdapat pada fraksi 2-4 dan 3-3 KK (Tabel 2). Kedua fraksi tersebut memiliki Rf yang sama sehingga digabungkan menjadi satu fraksi dengan label fr 2-4 KK $T v$. Hasil KLT fraksi tersebut menunjukkan bahwa fraksi tersebut lebih bersifat polar dibandingkan dengan senyawa standar rotenon.

Toksisitas Fraksi Aktif Ekstrak Daun T. vogelii serta Campurannya terhadap Larva C. Pavonana

Metode residu pada daun. Hasil pengujian fr 2-4 KK $T v$ menunjukkan adanya aktivitas insektisida yang kuat dengan pola perkembangan mortalitas

Tabel 1. Hasil fraksinasi ekstrak heksana daun T. vogelii dengan kromatografi vakum cair dan pengaruh letalnya terhadap larva C. Pavonana

\begin{tabular}{|c|c|c|c|}
\hline Fraksi & $\operatorname{Hasil}(\%)^{\mathrm{a})}$ & Faktor retensi ( $\mathrm{Rf})$ & $\begin{array}{c}\text { Mortalitas larva } C \text {. pavonana } \\
(\%)^{\text {b) }}\end{array}$ \\
\hline 1 & 16.82 & $0.93,0.96$ & 2.2 \\
\hline 2 & 31.83 & $0.36,0.57,0.86,0.93$ & 100.0 \\
\hline 3 & 24.72 & $0.36,0.57$ & 100.0 \\
\hline 4 & 11.02 & $0,0.36,0.46,0.54$ & 0.0 \\
\hline 5 & 14.30 & 0 & 0.0 \\
\hline Ekstrak kasar & - & $0,0.36,0.46,0.54,0.57,0.86,0.93,0.96$ & 80.0 \\
\hline
\end{tabular}

Keterangan : ${ }^{\text {a) }}$ Bobot fraksi relatif terhadap bobot ekstrak kasar, ${ }^{\mathrm{b})}$ Konsentrasi ekstrak/fraksi 0,14\% (w/v).

Tabel 2. Hasil pemisahan fraksi 2 dan 3 dari Tabel 1 dengan kromatografi kolom dan pengaruh letalnya terhadap larva C. Pavonana

\begin{tabular}{lclcr}
\hline Fraksi & Hasil $(\%)^{\mathrm{a})}$ & \multicolumn{1}{c}{ Faktor retensi (Rf) } & $\begin{array}{c}\text { Konsentrasi } \\
\text { uji }(\%)\end{array}$ & $\begin{array}{c}\text { Mortalitas larva } C . \\
\text { pavonana }(\%)^{\mathrm{b})}\end{array}$ \\
\hline $2-1$ & 8,39 & $0 ; 0.32 ; 0.54 ; 0.64 ; 0.75 ; 0.86$ & 0.037 & 35.6 \\
$2-2$ & 13.00 & $0 ; 0.32 ; 0.54 ; 0.64 ; 0.75$ & 0.057 & 95.6 \\
$2-3$ & 3.41 & $0.32 ; 0.64$ & 0.015 & 0.0 \\
$2-4$ & 4.37 & 0.54 & 0.019 & 80.0 \\
$2-5$ & 4.44 & 0 & 0.035 & 0.0 \\
$3-1$ & 0.24 & 0.86 & 0.035 & 0.0 \\
$3-2$ & 1.45 & $0.54 ; 0.64 ; 0.75$ & 0.035 & 100.0 \\
$3-3$ & 6.18 & 0.54 & 0.035 & 0.0 \\
$3-4$ & 0.38 & 0.32 & 0.035 & 0.0 \\
$3-5$ & 6.83 & 0 & 0.035 & 0.0 \\
\hline
\end{tabular}

Keterangan : ${ }^{\text {a) }}$ Bobot fraksi relatif terhadap bobot ekstrak kasar; ${ }^{\text {b) }}$ Mortalitas pada 72 JAP, metode residu pada daun. Pada kontrol tidak ada kematian larva 
larva instar II $C$. pavonana yang serupa. Kematian larva sebagian besar terjadi pada 24 dan 48 JAP (jam sejak awal perlakuan), sedangkan pada 72 JAP tingkat kematian larva umumnya hanya sedikit mengalami kenaikan. Hal ini disebabkan pada 48 JAP daun perlakuan sudah diganti dengan daun tanpa perlakuan dan pada 72 JAP residu ekstrak yang tertinggal di dalam tubuh larva uji sudah tidak dapat meningkatkan kematian serangga uji secara nyata. $\mathrm{LC}_{50}$ dan $\mathrm{LC}_{95}$ bahan uji pada 72 JAP tidak berbeda nyata dengan $\mathrm{LC}_{50}$ dan $\mathrm{LC}_{95}$ pada 48 JAP (SK $95 \%$ tumpang tindih) (Tabel 3).

Metode kontak. Perlakuan kontak dengan fr 2-4 $\mathrm{KK} T v$ pada konsentrasi $3.6 \times \mathrm{LC}_{95}$ metode residu pada daun mengakibatkan kematian larva $C$. pavonana sekitar $11 \%$, sedangkan perlakuan dengan profenofos pada konsentrasi $1 \times \mathrm{LC}_{95}$ dapat mengakibatkan kematian serangga uji sampai $100 \%$ Rendahnya efek kontak fraksi aktif $T v$ dapat disebabkan oleh beberapa hal, di antaranya waktu pemajanan (exposure) tidak dapat dilakukan lebih dari 2 jam karena serangga uji akan mati kelaparan. Faktor lain mungkin karena banyaknya bahan aktif ekstrak yang masuk ke dalam tubuh serangga setelah menembus kutikula jauh lebih sedikit dibandingkan dengan banyaknya komponen aktif ekstrak yang masuk ke dalam tubuh melalui saluran pencernaan makanan.

\section{Toksisitas Fraksi Aktif T. vogelii terhadap Larva P. Xylostella}

$\mathrm{LC}_{50}$ dan $\mathrm{LC}_{95}$ pada 72 JAP untuk setiap perlakuan tidak berbeda nyata dengan $\mathrm{LC}_{50}$ dan $\mathrm{LC}_{95}$ pada 48 JAP (Tabel 4), yang mencerminkan sudah tidak terjadi peningkatan kematian larva uji yang nyata antara 48 dan 72 JAP. Fraksi 2-4 KK Tv memiliki aktivitas insektisida yang kuat terhadap larva $P$. xylostella dengan $\mathrm{LC}_{95}$ pada 72 JAP hanya sekitar $0.031 \%$ (Tabel 4). Jenis bahan nabati tersebut dapat menjadi alternatif pengganti insektisda sintetik seperti profenofos yang sudah tidak efektif lagi terhadap larva $P$. xylostella $\left(\mathrm{LC}_{95} 7.3 \%\right.$ [Tabel 4], yang setara dengan $>24$ kali konsentrasi anjuran formulasi).

\section{Toksisitas Fraksi Aktif T. vogelii terhadap Imago Parasitoid D. Semiclausum}

Fraksi 2-4 KK $T v$ pada konsentrasi sampai $0.090 \%$ (3 kali $\mathrm{LC}_{95}$ terhadap larva inang $C$. pavonana atau 2 kali $\mathrm{LC}_{95}$ terhadap larva inang $P$. xylostella) hanya mengakibatkan kematian imago betina $D$. semiclausum sekitar 13\% (Tabel 5) sehingga fraksi ini cukup prospektif untuk dikembangkan sebagai bahan insektisida alternatif.

Tabel 3. Penduga parameter toksisitas ekstrak/fraksi T. vogelii terhadap larva instar II C. pavonana dengan metode residu pada daun

\begin{tabular}{ccccc}
\hline $\begin{array}{c}\text { Waktu pengamatan } \\
(\mathrm{JAP})\end{array}$ & $a \pm \mathrm{GB}^{\mathrm{a})}$ & $b \pm \mathrm{GB}^{\mathrm{b})}$ & $\mathrm{LC}_{50}(\mathrm{SK} 95 \%)(\%)^{\mathrm{b})}$ & $\mathrm{LC}_{95}(\mathrm{SK} 95 \%)(\%)$ \\
\hline Tv 2-4 & $4.31 \pm 0.57$ & $2.35 \pm 0.31$ & $0.015(0.011-0.020)$ & $0.074(0.042-0.337)$ \\
78 & $5.17 \pm 0.57$ & $2.62 \pm 0.30$ & $0.011(0.009-0.013)$ & $0.045(0.032-0.092)$ \\
Profenofos $^{\mathrm{c})}$ & & & & \\
48 & $7.87 \pm 0.67$ & $4.20 \pm 0.35$ & $0.013(0.011-0.016)$ & $0.033(0.025-0.053)$ \\
72 & $7.90 \pm 0.67$ & $4.18 \pm 0.35$ & $0.013(0.010-0.015)$ & $0.032(0.024-0.054)$ \\
\hline
\end{tabular}

Keterangan : ${ }^{a)}$ Kode singkatan bahan uji sudah dijelaskan di dalam teks; ${ }^{b} a$ dan $b$ masing-masing intersep dan kemiringan regresi probit; $\mathrm{GB}=$ galat baku; $\mathrm{SK}=$ selang kepercayaan; ${ }^{\mathrm{c})}$ Konsentrasi dalam \% formulasi $(\mathrm{v} / \mathrm{v})$.

Tabel 4. Penduga parameter toksisitas fraksi aktif $T$. vogelii terhadap larva instar II $P$. xylostella dengan metode residu pada daun

\begin{tabular}{ccccc}
\hline $\begin{array}{l}\text { Waktu Pengamatan } \\
(\mathrm{JAP})\end{array}$ & $a \pm \mathrm{GB}$ & $b \pm \mathrm{GB}$ & $\mathrm{LC}_{50}(\mathrm{SK} 95 \%)(\%)$ & $\mathrm{LC}_{95}(\mathrm{SK} 95 \%)(\%)$ \\
\hline Tv2-4 & & & & \\
48 & $5.13 \pm 0.88$ & $2.31 \pm 0.41$ & $0.006(0.005-0.007)$ & $0.031(0.021-0.068)$ \\
72 & & & \\
48 & $-3.77 \pm 0.72$ & $5.61 \pm 0.96$ & $4.692(4.001-5.17)$ & $9.225(7.840-12.98)$ \\
72 & $-4.73 \pm 0.83$ & $7.40 \pm 1.14$ & $4.359(3.890-4.70)$ & $7.271(6.600-8.55)$ \\
\hline
\end{tabular}

Keterangan : ${ }^{a}$ Kode singkatan bahan uji seperti dan keterangan lain seperti catatan kaki Tabel 3. 


\section{Uji Semilapangan terhadap C. pavonana}

Pada hari ke-3 dan 4 setelah infestasi pertama, perlakuan fr 2-4 KK $T v$ pada konsentrasi $3 \times \mathrm{LC}_{95}$ mengakibatkan penurunan populasi larva $C$. pavonana yang nyata dibandingkan dengan kontrol (Tabel 6). Penurunan jumlah larva secara drastis pada hari ke-7 disebabkan larva C. pavonana sudah berkepompong di dalam tanah sehingga sudah tidak dijumpai lagi pada tanaman.

Pada hari ke-3 setelah infestasi pertama, penurunan jumlah larva $C$. pavonana pada perlakuan fr 2-4 KK $T v$ sebesar 95\%. Sedangkan, pada tanaman kontrol terjadi penurunan jumlah larva $C$. pavonana sebesar $33.3 \%$ yang mungkin diakibatkan karena faktor musuh alami dan/atau tercuci hujan. Pada tanaman yang diberi perlakuan dengan insektisida sintetik profenofos dan bioinsektiasa $B$. thuringiensis, larva $C$. pavonana sudah tidak dapat ditemukan lagi pada hari ke-3 sejak infestasi pertama. Hal ini menunjukkan bahwa profenofos dan $B$. thuringiensis memiliki aktivitas yang kuat terhadap larva $C$. pavonana. Jumlah larva $C$. pavonana yang tersisa pada perlakuan dengan fr 2-4 KK $T v$ tidak berbeda nyata dengan perlakuan profenofos dan $B$. thuringiensis sehingga bahan nabati tersebut layak dikembangkan sebagai bahan insektisida alternatif.

Pada hari ke-4 setelah infestasi pertama, perlakuan dengan semua bahan uji tidak mengakibatkan penambahan jumlah larva yang mati per tanaman. Hal ini menunjukkan bahwa residu bahan uji sudah mengalami penurunan keaktifan baik karena penguraian oleh cahaya matahari, pencucian oleh hujan, atau karena larva uji sudah cukup besar dan lebih toleran. Data cuaca yang diperoleh dari Stasiun Klimatologi Darmaga Bogor selama berlangsungnya percobaan semilapangan menunjukkan curah hujan yang tinggi pada hari kedua dan keempat setelah infestasi pertama, masing-masing 33 dan $34 \mathrm{~mm}$.

Penurunan aktivitas residu bahan uji juga ditunjukkan pada tanaman kedua yang diinfestasi dengan larva $C$. pavonana 7 hari setelah infestasi pertama.

Tabel 5. Mortalitas imago parasitoid D. semiclausum yang diberi perlakuan fraksi aktif T. vogelii dengan metode kontak daun

\begin{tabular}{|c|c|c|c|c|c|c|c|}
\hline \multirow{3}{*}{ Bahan uji ${ }^{a)}$} & \multirow{3}{*}{$\begin{array}{c}\text { Konsentrasi } \\
(\%)\end{array}$} & \multicolumn{6}{|c|}{ Mortalitas (\%) imago pada waktu pengamatan (JAP) } \\
\hline & & \multicolumn{3}{|c|}{ Jantan } & \multicolumn{3}{|c|}{ Betina } \\
\hline & & 24 & 48 & 72 & 24 & 48 & 72 \\
\hline \multirow[t]{2}{*}{ Tv2-4 } & 0.090 & 13.3 & 26.7 & 80.0 & 10.0 & 13.33 & 13.3 \\
\hline & 0.045 & 3.3 & 10.0 & 33.3 & 0.0 & 3.33 & 6.7 \\
\hline \multirow[t]{2}{*}{ Profenofos } & 2.000 & 43.3 & 96.7 & 100.0 & 63.3 & 100.0 & 100.0 \\
\hline & 5.000 & 100.0 & 100.0 & 100.0 & 100.0 & 100.0 & 100.0 \\
\hline Kontrol & - & 0.0 & 0.0 & 3.3 & 0.0 & 0.0 & 0.0 \\
\hline
\end{tabular}

Keterangan : ${ }^{\text {a) }}$ Kode singkatan bahan uji seperti catatan kaki Tabel 3.

Tabel 6. Pengaruh fraksi aktif T. vogelii terhadap sintasan larva C. pavonana pada tanaman brokoli dalam pot di lapangan

\begin{tabular}{|c|c|c|c|c|c|c|c|}
\hline \multirow{3}{*}{ Perlakuan $^{\text {a) }}$} & \multirow{3}{*}{$\begin{array}{c}\text { Kon-sentrasi } \\
(\%)\end{array}$} & \multicolumn{6}{|c|}{ Populasi larva (ekor/tanaman) pada pengamatan hari ke-n ${ }^{\text {b) }}$} \\
\hline & & \multicolumn{3}{|c|}{ Infestasi I } & \multicolumn{3}{|c|}{ Infestasi II } \\
\hline & & 3 & 4 & 7 & 3 & 4 & 7 \\
\hline Tv2-4 & 0.135 & $0.75 b$ & $0.75 b$ & $0.25 \mathrm{a}$ & $6.25 \mathrm{a}$ & $6.25 \mathrm{a}$ & $0.25 \mathrm{a}$ \\
\hline Profenofos $^{c)}$ & 0.090 & $0.00 \mathrm{~b}$ & $0.00 \mathrm{~b}$ & $0.00 \mathrm{a}$ & $4.25 \mathrm{a}$ & $4.25 \mathrm{a}$ & $0.25 \mathrm{a}$ \\
\hline$B t^{\mathrm{c})}$ & 0.055 & $0.00 \mathrm{~b}$ & $0.00 \mathrm{~b}$ & $0.00 \mathrm{a}$ & $4.25 \mathrm{a}$ & $4.25 \mathrm{a}$ & $0.25 \mathrm{a}$ \\
\hline Kontrol & - & $10.00 \mathrm{c}$ & $10.00 \mathrm{c}$ & $0.25 \mathrm{a}$ & $6.75 \mathrm{a}$ & $6.75 \mathrm{a}$ & $0.25 \mathrm{a}$ \\
\hline
\end{tabular}

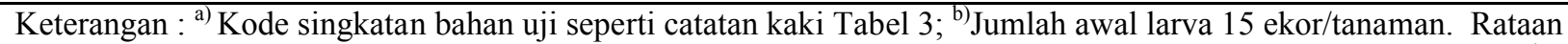
selajur yang diikuti huruf yang sama tidak berbeda nyata berdasarkan uji selang berganda Duncan $(\alpha=5 \%){ }^{\text {c) }}$ Konsentrasi dalam \% formulasi (w/v untuk $B t$ dan $\mathrm{v} / \mathrm{v}$ untuk profenofos). 


\section{EFIKASI INSEKTISIDA NABATI}

Pada semua perlakuan jumlah larva $C$. pavonana yang ditemukan kembali tidak berbeda nyata dengan kontrol.

\section{KESIMPULAN DAN SARAN}

Pemisahan dengan kromatografi kolom (KK) ekstrak daun $T$. vogelii (Tv) menghasilkan fr 2-4 KK $T v$ sebagai fraksi yang aktif terhadap larva $C$. pavonana dan P. xylostella. Komponen fr $2-4 \mathrm{KK}$ $T v$ lebih bersifat polar dibandingkan dengan standar rotenon berdasarkan KLT.

Fraksi 2-4 KK Tv memiliki aktivitas insektisida yang kuat terhadap larva $C$. pavonana dengan efek racun perut yang kuat dan efek racun kontak yang lemah. Berdasarkan $\mathrm{LC}_{50}$ pada $72 \mathrm{JAP}$, toksisitas fr 2-4 KK $T v 1.8$ kali lebih toksik terhadap larva $P$. xylostella dibandingkan terhadap $C$. pavonana.

Fraksi 2-4 KK $T v$ pada $2 \times \mathrm{LC}_{95}$ terhadap larva C. pavonana relatif aman bagi imago betina parasitoid D. semiclausum. Pada uji semilapangan, kemampuan fr 2-4 KK $T v$ dalam menurunkan populasi larva $C$. pavonana tidak berbeda nyata dengan insektisida sintetik profenofos dan bioinsektisda $B t$ sehingga fraksi tersebut layak dikembangkan.

Penelitian lapangan yang lebih luas dan pemilihan bentuk formulasi yang cocok masih perlu dilakukan untuk mengevaluasi lebih lanjut keefektifan sediaan $T$. vogelii sebagai insektisida alternatif.

\section{DAFTAR PUSTAKA}

Bentz, J, and J.W. Neal. 1995. Effect of a natural insectcide from Nicotiana gossei on the whitefly parasitoid Encarsia farmosa (Hymenoptera: Aphelinidae). J. Econ. Entomol. 88: 1611-1615.

Coats, JR. 1994. Risks from natural versus synthetic insecticides. Annu. Rev. Entomol. 39: 489-515.

Coll, JC., and B.F. Bowden. 1986. The application of vacuum liquid chromatography to the separation of terpene mixtures. J. Nat. Prod. 49: 934-936.

Delfel, NE., W.H. Tallent, D.G. Carlson, and I.A. Wolff. 1970. Distribution of rotenone and deguelin in Tephrosia vogelii and separation of rotenoid-rich fraction. J Agric Food Chem 188(3): 385-390.

Dono, D., D. Prijono, S. Manuwoto, dan D. Buchori. 1998. Pengaruh ekstrak biji Aglaia harmsiana Perkins terhadap interaksi antara larva Crocidolomia binotalis Zeller (Lepidoptera: Pyralidae) dan parasitoidnya, Eriborus argenteopilosus (Cameron) (Hymenoptera: Ichneumonidae). Bul HPT 10: 38-46.

Finney, D.J. 1971. Probit Analysis. 3rd Ed. The University Press, Cambridge UK
Hagemann, J.W., M.B. Pearl, J.J. Higgin, N.E. Delfel, and F.R. Earle. 1972. Rotenone and deguelin in Tephrosia vogelii at several stages of maturity. J. Agric. Food Chem. 20: 906-908.

Hollingworth, R.M. 2001. Inhibitors and uncouplers of mitochondrial oxidative phosphorylation. In: R. Krieger, J. Doull, D.Ecobichon, D. Gammon, E. Hogson, L. Reiter, and J. Ross (eds). Handbook of Pesticide Toxicology. Vol 2. San Diego: Academic Press. pp 1169-1227.

Isman, MB. 1995. Leads and prospects for development of new botanical insecticides. Rev. Pestic. Toxicol. 3: 120 .

Kalshoven, VDL. 1981. Pests of Crops in Indonesia. Van der Laan PA, Penerjemah. Jakarta: Ichtiar BaruVan Hoeve. Terjemahan dari: De Plagen van de Cultuurgewassen in Indonesië.

Kaufman, P.B., A. Kirakosyan, McKenzie, P. Dayanan, J.E. Hoyt, and C. Li. 2006. The uses of plant natural products by human and risks associated with their uses. In: L.J. Cseke, A. Kirakosyan, P.B. Kaufman, S.L. Warber, J.A. Duke, and H.L. Brielmann (eds). Natural Products from Plants. CRC Press, Boca Raton

Kosman, E., and Y. Cohen. 1996. Procedures for calculating and differentiating synergism and antagonism in action of fungicide mixtures. Phytopathology 86 : 1255-1264.

Lambert, N., M.F. Trouslot, C. Campa, and H. Chrestin. 1993. Production of rotenoids by heterotrophic and photomixotrophic cell cultures of Tephrosia vogelii. Phytochemistry 34: 1515-1520.

LeOra Software. 1987. POLO-PC User's Guide. LeOra Software, Petaluma (CA)

Marston, A., J.D. Msonthi, and K. Hostettmann. 1984. On the reported molluscisidal activity from Tephrosia vogelii leaves. Phytochemistry 23: 1824-1825.

Matsumura F. 1985. Toxicology of Insecticides. 2nd ed. Plenum Press, New York.

Metcalf, R.1. 1982. Insecticides in pest management. In: R.L. Metcalf, W.H. Luckman (eds). Introduction to Insect Pest Management. 2nd Ed. John Wiley, New York

Prijono, D. 1999. Prospek dan strategi pemanfaatan insektisida alami dalam PHT. In: B.W. Nugroho, Dadang, Priyono D (eds). Bahan Pelatihan Pengembangan dan Pemanfaatan Insektisida Alami; Bogor, 9 -13 Agustus 1999. Pusat Kajian PHT, Bogor

Rush, M., N. Rattanadilok, and N. Poapongsakorn. 1997. Pesticide use in Thai agriculture: problems and policies. In: N. Poapongsakorn, L. Meenakanit, H. Waibel, and F. Jungbluth (eds). A Policy Workshop 
in Hua Hin; Hua Hin, 3-5 Juli 1997. The Institute for Economics in Horticulture, Herrenhäuser, Hannover.

Sastrosiswojo, S., dan W. Setiawati. 1992. Biology and control of Crocidolomia binotalis in Indonesia. In: N.S. Talekar (ed.). Proceedings of the Second International Workshop on Diamondback Moth and other Crucifer Pests; Tainan, 10-14 Desember 1990. Tainan: AVRDC. pp 81-90.

Sastrosiswojo B, dan W. Setiawati. 1993. Hama-hama tanaman kubis dan cara pengendaliannya. In: A.H. Permadi dan S. Sastrosiswojo (eds). Kubis. Balitbang Pertanian dan Balai Penelitian Hortikultura, Bandung.

Schmutterer, H. 1997. Side-effect of neem (Azadirachta indica) products on insect pathogens and natural enemies of spider mites and insects. J Appl. Entomol. 121: 121-128.
Setiawati, W, Sastrosiswojo. 1995. Penerapan komponen teknologi PHT pada tanaman kubis di dataran tinggi dan dataran medium. Prosiding Seminar Ilmiah Nasional Komoditas Sayuran; Lembang, 24 Oktober 1995. Balai Penelitian Tanaman Sayuran, Bandung. pp 347-354.

Smith, D. 1975. Cabbage pest control investigations. Queensl J Agric Anim Sci 32: 13-18.

Talekar, N.S., and A.M. Shelton. 1993. Biology, ecology, and management of the diamondback moth. Annu. Rev. Entomol. 38: 275-301. 